\title{
Domingos Arouca: um percurso de militância nacionalista em Moçambique*
}

\author{
Carolina Barros Tavares Peixoto** \\ Maria Paula Meneses***
}

\begin{abstract}
RESUMO
Neste trabalho apresentamos uma releitura das disputas em torno da história e da memória em Moçambique a partir da análise do percurso de militância de Domingos Arouca. Enfatizando sua condição de nacionalista e preso político até o início dos anos 1970, este texto assenta na análise de documentos reunidos em arquivos moçambicanos e portugueses, em notícias publicadas em jornais e revistas e em entrevistas com outros nacionalistas. Este vasto espólio tornou possível uma leitura mais densa e complexa das memórias e dos processos políticos relacionados com um período menos conhecido da história de Moçambique: o fim do período colonial e a transição para a independência (1962-1975). Esta contribuição visa ampliar as possibilidades de construção de uma perspectiva mais sofisticada sobre os processos de reconstrução identitária no Moçambique contemporâneo.
\end{abstract}

Palavras-chave: Moçambique; Domingos Arouca; memórias; história; identidade.

\begin{abstract}
This paper offers a reinterpretation of disputes over history and memory in Mozambique from the analysis of Domingos Arouca's militant path. It emphasizes the political path of Arouca, a nationalist and political prisoner until the early 1970s. The study is based on archival research carried out both in Mozambique and Portugal, analysis of media, as well as on interviews carried out with other nationalists. It proposes a more dense and complex interpretation of the political history and social memories of a lesser known period of Mozambique history - the end of colonialism and the transition to independence (1962-1975). This paper aims to be a contribution towards a more sophisticated perspective over the processes of identity reconstruction in contemporary Mozambique.
\end{abstract}

Keywords: Mozambique; Domingos Arouca; memories; history; identity.

Artigo recebido em 5 setembro de 2012 e aceito em 9 de maio de 2013.

* Este artigo foi produzido no âmbito do projeto de investigaçáo “'Os Comprometidos': questionando o futuro do passado em Moçambique”, com financiamento da Fundação para a Ciência e Tecnologia (FCT) de Portugal. Agradecemos aos comentadores anônimos cujas sugestóes contribuíram para clarificar e fortalecer nosso argumento.

** Doutoranda em pós-colonialismos e cidadania global pela Universidade de Coimbra. Coimbra, Portugal. E-mail: carolinapeixoto@ces.uc.pt.

*** Doutora em antropologia pela Universidade de Rutgers, New Jersey, EUA, pesquisadora do Centro de Estudos Sociais da Universidade de Coimbra. Coimbra, Portugal. E-mail: menesesp@ces.uc.pt. 


\section{Introdução}

As histórias de muitos dos modernos Estados-nação que resultaram da violência da relação colonial são atravessadas por conflitos políticos de pertença e reconhecimento e pelas implicações morais e materiais inerentes a tais conflitos. Em contextos como os de Moçambique, o projeto constituinte da nação incluiu a adoção de uma história oficial baseada num conjunto de memórias públicas e intensamente publicitadas sobre o passado colonial e a luta de libertação nacional. Esta estratégia política adotada pela Frelimo ${ }^{1}$ promoveu o silenciamento de uma diversidade de memórias geradas pelas sempre complexas interaçóes sociais estabelecidas entre colonizadores e colonizados, além de escamotear uma variedade de tensôes e antagonismos que permeavam (e ainda permeiam) a sociedade moçambicana.

Volvidos quase quarenta anos desde a declaração da independência, começam a emergir debates mais ou menos intensos sobre a política da história e da memória em Moçambique. Para tanto têm contribuído enormemente as recentes publicaçôes de (auto)biografias e relatos de memória produzidos pelos protagonistas da história contemporânea moçambicana, ${ }^{2}$ dentre os quais destacam-se ex-presos políticos e altos funcionários do governo que integram o partido Frelimo, incluindo o antigo presidente Joaquim Chissano. ${ }^{3} \mathrm{O}$ aparecimento destas obras chama a atenção para a existência de outras narrativas sobre o passado moçambicano, desafiando a historiografia oficial e fomentando a discussão sobre que e, sobretudo, por que fatos, feitos e personagens foram incluídos ou excluídos da história recente do país.

Aproveitando este momento de abertura para o debate, este trabalho procura contribuir para o desenvolver de uma cartografia mais densa e complexa das memórias e processos políticos relacionados tanto com o período de transição da fase colonial para a pós-colonial em Moçambique, quanto com o período de democratizaçáo política do país.

O texto centra-se na análise do percurso de militância do dr. Domingos Arouca, um dos protagonistas do já referido período da história contemporânea moçambicana, que faleceu sem publicar suas memórias ou uma autobiografia. Observando suas vivências como militante nacionalista e preso político, em contraponto com a análise de documentos reunidos em arquivos, bem como de notícias publicadas em jornais e revistas, esperamos ajudar a desvelar algumas das tensôes e dos confrontos que refletem a intensidade das disputas pela política da história e da memória em Moçambique. Disputas essas que, apesar de terem ganhado maior notoriedade nos últimos anos, também têm uma história, como sugere o episódio relatado pelo militante e ex-preso político Aurélio Valente Langa:

\footnotetext{
${ }^{1}$ Frente de Libertação de Moçambique. Principal movimento nacionalista que liderou a luta armada contra a dominação colonial portuguesa. No final dos anos 1970, já após a independência, estabeleceu-se como partido político, tendo-se mantido na liderança governativa quer em contextos de partido-Estado, quer de multipartidarismo.

${ }^{2}$ Veja-se: DICK, Jorge. Mandionerepi. Maputo: Centro de Pesquisa da História da Luta de Libertação Nacional, 2011; FERRÃO, Valeriano. Embaixador nos USA. Maputo: Ndjira, 2007; LANGA, Aurélio Valente. Memórias de um combatente da causa. Maputo: JV Editores, 2011; MATEUS, Dalila Cabrita; MATEUS, Álvaro. Nacionalistas de Moçambique. Maputo: Texto Editora, 2010; MATSINHA, Mariano; SAMPAIO, José. Um homem, mil exemplos: a vida e luta de Mariano Araújo Matsinha. Maputo: Plural Editores, 2012; MBOA, Matias. Memórias da luta clandestina. Maputo: Marimbique, 2009; MOIANE, José. Memórias de um guerrilheiro. Maputo: King Ngungunhane Institute, 2009; NCOMO, Barnabé L. Uria Simango: um homem, uma causa. Maputo: Ediçóes Novafrica, 2003; PACHINUAPA, Raimundo (Org.). Memórias da Revolução 1962-1974. Maputo: Centro de Pesquisa da História da Luta de Libertação Nacional e Associação Nachingwea, 2011; PELEMBE, João. Lutei pela pátria. Maputo: Ed. do autor, 2012; VELOSO, Jacinto Soares. Memórias em voo rasante. Maputo: Papa-Letras, 2006; VIEIRA, Sérgio. Participei, por isso testemunho. Maputo: Ndjira, 2010; ZAWANGONI, Salvador André. A Frelimo e a formação do homem novo. Maputo: CFM, 2007.

${ }^{3}$ CHISSANO, Joaquim. Vidas, lugares e tempos. Maputo: Texto Editores, 2011. v. 1.
} 
Logo no $2^{\circ}$ dia da reuniāo, ${ }^{4}$ fomos explicados que a expressão "ex-prisioneiro político" terminaria ali, já não se podia exibir. Não tivemos a explicação do porquê. Todos passámos a ser chamados de combatentes. Concordámos, na verdade somos combatentes, mas não compreendemos por que é que a designação "ex-pp" ficou extinta, sem mais explicação. ${ }^{5}$

Em busca de explicaçóes que permitam compreender o porquê do apagamento dos ex-pps e seus percursos de luta clandestina da narrativa histórica oficial, na primeira parte deste trabalho procuraremos escrutinar os momentos de grande intensidade conflitual e transformadora próprios do processo de construção do Estado-naçáo em Moçambique para produzir uma análise crítica do projeto de identidade nacional implementado pela Frelimo, projeto esse que passou a definir quem eram os moçambicanos, para onde iam, por que meios e com que referenciais ideológicos.

Em 1986, Aquino de Bragança e Jacques Depelchin já questionavam se produzir uma história da luta armada dirigida pela FRELIMO permitiria, automaticamente, compreender a história global da luta nacionalista ao nível do país. ${ }^{6}$ Reconhecendo que, apesar de a guerrilha levada a Moçambique pela FRELIMO ter sido lançada em setembro de 1964, "o trabalho de politização e a resistência local às barbaridades [perpetradas pelo colonialismo], nomeadamente do trabalho forçado, vinham de muito antes", 7 entendemos que, para compreender de fato a complexidade da história global do processo de transiçáo para a independência e construção do Estado-nação moçambicano, importa propor novas questóes à história, introduzindo outros atores e temas para além daqueles já consolidados pela historiografia oficial.

Como bem nos alertam Bragança e Depelchin, "na história, como em qualquer ciência, é necessário, às vezes, voltar atrás e requestionar os conhecimentos considerados como definitivos". ${ }^{8}$ Portanto, nosso primeiro passo será "requestionar" a história oficial procurando destacar o fato de que, dos anos 1960 até a declaração da independência, em 1975, o nacionalismo moçambicano conheceu expressôes muito mais complexas do que tem sido veiculado.

Depois de apresentar a complexidade do cenário político moçambicano e do processo de luta de libertação nacional, que incluiu variadas estratégias de negociação e construção de alianças, passaremos a analisar o percurso de militância de Domingos Arouca. Tentaremos então elucidar os motivos que fizeram com que esta figura de grande força e notoriedade política, uma vez que esteve entre os primeiros intelectuais moçambicanos negros que abraçaram e fomentaram o nacionalismo, tenha sido silenciada. Para tanto, incluiremos uma discussão sobre como a Frelimo, quer ainda como um movimento de libertação nacional, quer como partido de vanguarda marxista-leninista, buscou definir o "homem novo", idealizando o cidadão do Moçambique independente, em oposição à figura do "inimigo"10 construída a partir da perspectiva adotada ainda durante a guerra nacionalista, segundo a qual "quem não está conosco está contra nós".

\footnotetext{
${ }^{4}$ Em março de 1978 a direção do partido Frelimo realizou uma reunião com os ex-presos políticos onde se discutiram situaçôes de suposto colaboracionismo nas cadeias da Pide — polícia política portuguesa. Esta suspeita mancharia, de forma dramática, o currículo político de muitos dos antigos presos políticos. LANGA, Aurélio Valente. Memórias de um combatente da causa, op. cit. p. 368-369.

${ }^{5}$ Ibid., p. 369.

${ }^{6}$ BRAGANÇA, Aquino de; DEPELCHIN, Jacques. Da idealização da Frelimo à compreensão da história de Moçambique. Estudos Moçambicanos, Maputo, n. 5/6, p. 29-52, 1986.

${ }^{7}$ VVAA. Tortura na colónia de Moçambique, 1963-1974: depoimentos de presos políticos. Porto: Afrontamento, 1977. p. 5-6. ${ }^{8}$ BRAGANÇA, Aquino de; DEPELCHIN, Jacques. Da idealização da Frelimo à compreensão da história de Moçambique, op. cit. p. 33.

${ }^{9}$ FRELIMO. O processo revolucionário da guerra popular de libertação. Maputo: Departamento do Trabalho Ideológico da Frelimo, 1977.

${ }^{10}$ MACHEL, Samora Moisés. Declaramos guerra ao inimigo interno: texto integral do discurso pronunciado no dia 18 de março de 1980. São Paulo: Quilombo, 1980.
} 


\section{A complexidade política da luta de libertação nacional — entre disputas, negociações, alianças e "traiçóes"}

A FRELIMO surgiu em decorrência de um processo de negociaçôes que levou à união de três organizaçôes nacionalistas, a União Democrática Nacional de Moçambique (Udenamo), a Mozambique African National Union (Manu) e a União Nacional Africana de Moçambique Independente (Unami), de caráter regional, ${ }^{11}$ com o objetivo de agregar forças na luta pela independência nacional, forjando uma frente comum para liquidar o colonialismo português e todos os vestígios do imperialismo. ${ }^{12}$

Nos dias de hoje, o Secretariado do partido Frelimo define Eduardo Mondlane, ${ }^{13}$ primeiro presidente da Frente, como "uma espécie de farol e ideólogo que guiava os moçambicanos na luta pela sua liberdade". ${ }^{14}$ As ideias defendidas por este intelectual tiveram grande peso na definição dos princípios básicos de orientação da FRELIMO, da natureza e dos objetivos da luta de libertação nacional; e também na caracterização do inimigo contra o qual os nacionalistas moçambicanos deviam lutar. A este respeito, Mondlane afirmaria, em Dar-es-Salam, a 3 de dezembro de 1964:

(...) Por nacionalismo entendo "uma tomada de consciência por parte de indivíduos numa nação ou de um desejo de desenvolver a força, a liberdade ou a prosperidade dessa naçăo". (...) Dadas as recentes circunstâncias históricas que afetaram as vidas dos vários povos do continente africano, é necessário acrescentar que o nacionalismo africano também se caracteriza pelo desenvolvimento de atitudes, atividades e programas mais ou menos estruturados com vista à mobilização de forças para conseguir a autodeterminaçáo e a independência. No caso específico de Moçambique, estas atitudes, atividades e programas estruturados, comuns a todas as colônias portuguesas em África e possivelmente aos outros povos náo livres, têm que incluir a organização de planos militares ou paramilitares para a luta final antes de a independência poder ser assegurada..$^{15}$

\footnotetext{
${ }^{11}$ Sobre este processo veja-se, entre outros, CAHEN, Michel. Anticolonialism and nationalism: deconstructing synonymy, investigating historical processes. In: MORIER-GENOUD, Éric (Org.). Sure road? Nations and nationalisms in Guinea, Angola and Mozambique. Leiden: Brill, 2012. p. 1-30.

${ }^{12}$ Veja-se o documento sobre a constituição da FRELIMO, de 1962, no maço "Dossier do SCCIM referente a elementos da FRELIMO — Frente de Libertação de Moçambique" (1963-1965), Arquivo Histórico Diplomático, Fundo do Ministério do Ultramar, Governo de Moçambique/Gabinete dos Negócios Políticos, com a cota RNP/0025/12029.

${ }^{13}$ Eduardo Mondlane (Gaza, 1920 — Dar-es-Salam, 1969), celebrado como o 'arquiteto da unidade nacional' moçambicana. Em 1938 concluiu o ensino primário, o grau mais elevado permitido aos negros em Moçambique naquela altura. Em 1944, recebeu uma bolsa para continuar os estudos no Transvaal Norte, África do Sul. Terminado o ensino secundário, ingressou no curso de ciências sociais da Universidade de Witwatersrand, em Johannesburg. Inspirado pelo exemplo do movimento estudantil sul-africano, promoveu, em Moçambique, a organização do Núcleo de Estudantes Secundaristas Africanos de Moçambique (Nesam), associação que, à guisa de promover atividades culturais e sociais, serviu, clandestinamente, para iniciar a organização política da juventude moçambicana em torno da ideia de independência nacional. Por desenvolver atividades políticas via participação no movimento estudantil, Mondlane teve sua autorização de permanência na África do Sul revogada ao fim do primeiro ano de estudos universitários, tendo sido deportado para Moçambique. Em junho de 1950 seguiu para Lisboa, para continuar os estudos. Na metrópole conheceu outros estudantes oriundos das colônias africanas. Apesar da estreita vigilância a que estavam submetidos, esses estudantes formaram uma rede embrionária anticolonial pela qual passaram os principais dirigentes da luta contra a dominação portuguesa em África. Em 1951, Mondlane partiu para os EUA onde concluiu seus estudos, tendo-se doutorado em 1960. Entre 1957 e 1961 Mondlane trabalhou para a ONU tendo visitado várias colónias africanas, o que lhe permitiu entrar em contato com a realidade social e política de outros povos colonizados. Em 1962, aderiu à luta nacionalista que dirigiu até sua morte, provocada por uma carta bomba.

${ }^{14}$ FRELIMO. Alguns dados biográficos do dr. Eduardo Chivambo Mondlane, fundador e primeiro presidente da Frelimo o Arquitecto da Unidade Nacional. Maputo: Secretariado do Comité Central do Partido Frelimo, 2009. Disponível em: <http:// macua.blogs.com/files/vida-e-obra-de-vida-de-eduardo-mondlane.pdf >. Acesso em: 9 maio 2012.

${ }^{15}$ MONDLANE, Eduardo. Apud BRAGANÇA, Aquino de; WALLERSTEIN, Immanuel (Org.). Quem é o inimigo (II)? Os Movimentos de Libertação Nacional. Lisboa: Iniciativas Editoriais, 1978 [1964]. p. 33-34.
} 
Deste excerto depreendemos que, se a perspectiva adotada pela FRELIMO em relação à opção socioeconômica para o Moçambique independente era ainda difusa, o objetivo central do movimento e a definição do inimigo do moderno nacionalismo moçambicano eram já bastante precisos.

As resoluçóes adotadas durante o I Congresso da FRELIMO (1962) mostram que um dos elementos fundamentais na estruturação do projeto ideológico do movimento foi a produção simbólica do inimigo: o colonialismo e todas as ameaças à unidade do movimento. ${ }^{16} \mathrm{Ou}$ seja, desde o início o inimigo foi identificado como externo - o colonialismo - e interno - as ameaças à unidade do movimento. Zawangoni ${ }^{17}$ registra que, para preservar a unidade, combatendo o tribalismo, o racismo, a discriminação contra a mulher etc., e difundir a conscientizaçáo sobre as razóes e a natureza da luta, a educação política seria um dos pilares da preparação ideológica dos militantes nacionalistas. Contudo, apesar deste esforço para consolidar a unidade, o projeto da FRELIMO não ficaria incólume à contestação interna, do que resultariam várias fraturas. ${ }^{18}$

Não obstante a força e a eficácia inicial do programa básico elaborado durante o I Congresso, como nos alertam Aquino de Bragança e Immanuel Wallerstein, "as perspectivas dos movimentos [nacionalistas] não estão fixadas. Amadurecem e tornam-se mais claras, talvez mais elaboradas ou mais específicas, à medida que o tempo e a luta se desenrolam. A sua teoria evolui da práxis" ${ }^{19}$ Com a FRELIMO não seria diferente. À medida que a luta foi se intensificando, de frente nacional este movimento gradualmente se transformou num partido de inspiração marxista-leninista. Numa entrevista concedida a Aquino de Bragança em 1968, logo a seguir ao II Congresso, Mondlane afirmava:

Uma base comum que todos tínhamos quando formamos a FRELIMO era o ódio ao colonialismo, a necessidade de destruir a estrutura colonial e impor uma nova estrutura social... mas que tipo de estrutura social ninguém sabia. Alguns sabiam, tinham ideias teóricas, mas mesmo esses foram transformados pela luta. Há uma evolução de pensamento que se operou durante os últimos seis anos que me pode autorizar, que eu me autorizo a mim mesmo concluir, que a FRELIMO é agora, realmente, muito mais socialista, revolucionária e progressista, do que nunca, e a tendência agora é mais e mais em direção ao socialismo do tipo marxista-leninista. Porque as condiçóes de vida em Moçambique, o tipo do inimigo que nós temos, não admite qualquer outra alternativa. ${ }^{20}$

Contudo, essa transição não ocorreu sem problemas. No final da década de 1960, a FRELIMO teve de lidar com uma agudização das contradiçôes — políticas, militares e administrativas — que a fraturavam tão profundamente ao ponto de causar a morte de vários dos seus líderes, incluindo a do seu presidente, Eduardo Mondlane. O conflito provocado pela dualidade de poderes que opunha as lideranças tradicionais, vistas como reacionárias, aos revolucionários cada vez mais estruturados em torno de um projeto político-militar explica, grosso modo, a macrocisão no seio do movimento. Estas duas linhas, especialmente visíveis após o II Congresso, discordavam quanto às estratégias a prosseguir na luta (não foram poucos aqueles a questionar a validade e, sobretudo, a capacidade de manutenção

\footnotetext{
${ }^{16}$ Boletim no 1 da Frente de Libertação de Moçambique, de dezembro de 1962. Este documento é parte integrante do maço "Dossier do SCCIM referente a elementos da Frelimo - Frente de Libertação de Moçambique" (1963-1965), Arquivo Histórico Diplomático, Fundo do Ministério do Ultramar, Governo de Moçambique/Gabinete dos Negócios Políticos, com a cota RNP/0025/12029.

${ }_{17}$ ZAWANGONI, Salvador André. A Frelimo e a formação do homem novo, op. cit.

${ }^{18}$ NCOMO, Barnabé L. Uria Simango: um homem, uma causa, op. cit.

19 BRAGANÇA, Aquino de; WALLERSTEIN, Immanuel (Org.). Quem é o inimigo (I)? Anatomia do colonialismo. Lisboa: Iniciativas Editoriais, 1978. p. 20.

${ }^{20}$ MONDLANE, Eduardo. Apud BRAGANÇA, Aquino de; WALLERSTEIN, Immanuel (Org.). Quem éo inimigo (II)?, op. cit. p. 200-201.
} 
de uma guerra prolongada), quanto à importância dada à luta armada em relação a outras formas de luta e quanto à definiçáo de quem era o inimigo (o sistema colonial ou os brancos encarados como a personificação deste sistema de exploração). ${ }^{21}$

Este avolumar das contradiçôes internas no seio da liderança do movimento nacionalista levou Uria Simango, então seu vice-presidente, a publicar o documento intitulado "Situação sombria na FRELIMO". ${ }^{22}$ Neste documento Simango criticava a radicalização da revolução, expondo abertamente os conflitos que o movimento atravessava. Esta tomada de posição pública foi interpretada como uma manifestação do "inimigo interno", servindo aos interesses do colonialismo e do imperialismo português. Simango foi acusado de traição pela ala revolucionária, na liderança da Frente. Estas duas linhas confrontar-se-iam até que, em 1970, Simango foi finalmente expulso da FRELIMO. As razóes elencadas pelo Comitê Central para justificar o afastamento deste membro fundador incluíam acusaçôes de oportunismo, corrupção e irresponsabilidade, apontando este comportamento como uma ameaça à legitimidade e à continuidade da luta. ${ }^{23} \mathrm{Ou}$ seja, o questionar da opção progressista da luta, quer na frente militar, quer na sua componente econômica e administrativa, passou a ser interpretado como uma traição não só à própria luta de libertação nacional, como também à "confiança que o povo moçambicano havia depositado nessas pessoas" 24 como representantes da FRELIMO. De acordo com a leitura de Bragança, ${ }^{25}$ a defesa dos interesses das massas deserdadas de Moçambique emergiu, então, com tanta força como a da luta contra os "novos exploradores", presentes no seio da própria FRELIMO.

Feita esta primeira "limpeza" no Comitê Central, o movimento reagrupou-se em torno de Samora $\mathrm{Machel}^{26}$ e sua política de ataque à "corrupção material, espiritual e ideológica" 27 que rondava os militantes nacionalistas e comprometia o sucesso da revolução. Machel combateu, como militar, o colonialismo português em Moçambique, envolvendo-se também no aprofundar da luta política para promover uma transformação radical da sociedade moçambicana. Transformação que teve início com a radicalizaçáo da postura política da própria FRELIMO quando esta passou a assumir sua opção pelo socialismo.

Em novembro de 1970, quando questionado numa entrevista realizada em Bruxelas sobre a ideologia que embasava a atuação da FRELIMO, Joaquim Chissano, na altura membro do Comitê Central deste movimento, respondeu:

A FRELIMO foi criada para combater o colonialismo português, ou seja, para combater um sistema de exploração, um sistema de opressão, um sistema não democrático. A FRELIMO quer criar um Moçambique unido e democrático, isto é, onde o povo possa escolher o seu governo, participar nele e tomar parte na discussão dos assuntos do país.

\footnotetext{
${ }^{21}$ FRELIMO. Self-criticism. In: BRAGANÇA, Aquino de; WALLERSTEIN, Immanuel (Org.). The African Liberation Reader. Vol. 2: the national liberation movements. Londres: Zed Press, 1982 [1969]. p. 122-124.

${ }^{22}$ A tradução do original em inglês "Gloomy situation in FRELIMO" é de nossa inteira responsabilidade. Este documento é parte integrante do maço "PIDE/DELEGAÇĀO DE MOÇAMBIQUE, Assunto: Uria Simango, Informação nº 1299CI (2), Lourenço Marques, 30 de dezembro de 1969”, ANTT - PIDE/DGS, Processo 2826/62, FRELIMO, vol. 1.

${ }^{23}$ FRELIMO. O processo revolucionário da guerra popular de libertação, op. cit. p. 140-142.

${ }^{24}$ Ibid., p. 141.

${ }^{25}$ BRAGANÇA, Aquino de. Le Marxisme de Samora. Afrique Asie, n. 217, p. xix-xxii, jul. 1980.

${ }^{26}$ Samora Moisés Machel (Chilembene, 1933 - África do Sul, 1986), filho de pequenos agricultores empobrecidos. Frequentou a escola católica e formou-se enfermeiro. Em 1962 aderiu à FRELIMO, tendo, no ano seguinte, recebido treinamento militar na Tanzânia e na Argélia. Participou, em 1964, nos primeiros ataques guerrilheiros em território moçambicano. Em maio de 1970 foi eleito presidente da FRELIMO pelo Comitê Central do movimento. Foi o primeiro presidente do país. Morreu vítima de um desastre aéreo.

${ }^{27}$ MACHEL, Samora. Apud BRAGANÇA, Aquino de; WALLERSTEIN, Immanuel (Org.). Quem é o inimigo (II)?, op. cit. p. 212.
} 
Por outro lado, a FRELIMO quer criar um sistema econômico onde não exista a exploração do homem pelo homem. (...) É esta a nossa política e a nossa política externa. Posso acrescentar que defendemos o socialismo como sendo a via de desenvolvimento que conduz o homem à dignidade. ${ }^{28}$

Mas Samora Machel parecia consciente de que implementar o socialismo em Moçambique não seria uma tarefa simples. Pois, como afirmava num discurso proferido em 1973,

(...) A luta de classes no plano internacional, entre o nosso povo e o inimigo colonialista e imperialista, sucede-se no plano interno, a luta de classes contra as forças nacionais com vocação exploradora.

Quer isto dizer ainda que a demarcação anterior entre colonizados e colonizadores tem que ser completada por uma demarcaçáo mais profunda ainda, entre explorados e exploradores.

Esta demarcação atinge todos os níveis, e primeiramente o nível ideológico e cultural. (...)

Acontece que todos nós nascemos e crescemos na sociedade exploradora, fomos profundamente impregnados da sua ideologia e cultura, por isso é-nos difícil e por vezes parece-nos impossível o combate interno, contra o que cremos constituir o nosso esqueleto moral.

Arrancar de nós a ideologia e a cultura exploradora para assumirmos e vivermos, no detalhe do quotidiano, a ideologia e a cultura requeridas pela revoluçáo, constitui a essência do combate pela criação do homem novo. ${ }^{29}$

Ou seja, para transformar radicalmente a sociedade moçambicana, de acordo com a evolução do projeto de nação defendido pela FRELIMO, era preciso promover uma profunda mudança de mentalidade entre os moçambicanos. E, assim, a projeção daqueles que seriam os futuros cidadãos do Moçambique independente passou a associar-se cada vez mais à construção do "homem novo", moldado a partir dos exemplos dos camponeses e dos guerrilheiros vivendo nas zonas libertadas, territórios vistos como "o laboratório científico do futuro Moçambique independente". ${ }^{30} \mathrm{Nas}$ zonas libertadas funcionava

(...) uma forma embrionária do Estado Popular, defensor dos interesses das classes mais exploradas e oprimidas da sociedade. Os novos organismos de Poder continham os princípios da democracia, da participação ampla das massas, dos militantes e dos combatentes na resolução dos problemas da guerra, da produção, do comércio, da educação, da saúde, em suma, da organização da vida coletiva em cada região. O Estado Popular não se encontrava distanciado do Povo nem se impunha a ele. Pelo contrário, ia de encontro às suas necessidades imediatas e aos seus anseios mais profundos de liberdade e democracia. ${ }^{31}$

O "homem novo" era portador de uma nova cultura "desenvolvida a partir de formas tradicionais, agora com um novo conteúdo ditado pela nova realidade (...): a luta de libertaçáo e o esforço comum dos moçambicanos oriundos de diferentes partes e tribos". ${ }^{32}$ Educar o "homem novo" pressupunha "destruir as ideias e hábitos corruptos herdados do passado; desenvolver o espírito científico para eliminar a superstiçáo; promover a emergência de uma cultura nacional, liquidar o individualismo e o elitismo". 33

${ }^{28}$ CHISSANO, Joaquim. Apud BRAGANÇA, Aquino de; WALLERSTEIN, Immanuel (Org.). Quem é o inimigo (II)?, op. cit. p. $174-175$.

${ }^{29}$ MACHEL, Samora. Apud Ibid., p. 175-177.

${ }^{30}$ BRAGANÇA, Aquino. Le Marxisme de Samora, op. cit. p. xxii.

${ }^{31}$ MACHEL, Samora. O partido e as classes trabalhadoras moçambicanas na edificação da democracia popular. Lisboa: Edições Avante, 1978. p. 144.

${ }^{32}$ FRELIMO. Revolutionary education. In: BRAGANÇA, Aquino de; WALLERSTEIN, Immanuel (Org.). The African Liberation Reader. V. 3: the strategy of liberation. Londres: Zed Press, 1982 [1969]. p. 194-196.

${ }^{33}$ Ibid., p. 195. 
Porém, nem todos os moçambicanos participaram da luta armada ou viveram em zonas libertadas. E, mesmo entre aqueles que participaram desta experiência, houve quem encontrasse dificuldades em se encaixar nesse padrão tão específico da ideia de moçambicanidade defendido pela FRELIMO.

\section{A (i)legitimidade da pertença: o caso de Domingos Arouca}

Domingos Arouca foi um dos personagens da história política contemporânea moçambicana que não se adequou à ideia de moçambicanidade defendida pelo partido Frelimo ao longo das décadas de 1970 e 1980.

Domingos António Mascarenhas Arouca (Inhambane, 1928 - Maputo, 2009), nascido numa família de pequenos proprietários rurais, formou-se primeiro como enfermeiro em Moçambique. Em 1949, ganhou um prêmio na loteria que lhe permitiu custear os próprios estudos em Portugal onde concluiu o liceu e cursou a Faculdade de Direito da Universidade de Lisboa, formando-se em 1960. ${ }^{34}$

Em 1961, Arouca tornou-se conselheiro jurídico do Banco Nacional Ultramarino (BNU). Em junho de 1963 instalou-se em Lourenço Marques, ${ }^{35}$ quando sua solicitação de transferência para a agência do BNU nesta cidade foi deferida. Na altura, tornou-se também membro do Tribunal Administrativo de Moçambique, cargo que rapidamente abandonou, por razóes políticas. Pelas mesmas razóes, já em 1964, demitiu-se das funçóes de conselheiro jurídico do BNU, passando a dedicar-se inteiramente à advocacia na circunscrição judiciária de Lourenço Marques. Em março de 1965 Arouca foi eleito presidente do Centro Associativo dos Negros de Moçambique, um dos importantes polos de reivindicação nacionalista na então colônia. Pouco depois, em 29 de maio, foi preso pela Pide, ${ }^{36}$ acusado de pertencer à FRELIMO. ${ }^{37} \mathrm{O}$ Centro Associativo, que funcionou clandestinamente como espaço de reuniáo para vários nacionalistas, que entretanto também haviam sido presos, foi encerrado.

A prisão de Arouca aconteceu na sequência de uma série de outras detençóes que puseram fim ao sistema de células clandestinas instalado na capital do território moçambicano que serviu de base para a formação da "Frente Sul" - correspondente às atuais províncias de Inhambane, Gaza e Maputo —, que tinha por objetivo criar no extremo sul de Moçambique as bases para a preparaçáo do início da luta armada fundando a "IV ${ }^{a}$ Regiāo" Político-Militar da FRELIMO.$^{38}$ Além de Domingos Arouca, fizeram parte da Frente Sul outros elementos da chamada "pequena-burguesia" local como o jornalista Albino Magaia, o pintor Malangatana Valente, os escritores José Craveirinha, Rui Nogar e Luís Bernardo Honwana, entre muitos outros militantes. Todos acabaram nas cadeias da Pide antes que a IV entrasse, de fato, em funcionamento. Mas tal não coibiu as autoridades coloniais de aumentarem a repressão, prendendo e condenando muitos nacionalistas. ${ }^{39}$

\footnotetext{
${ }^{34}$ Sobre as dificuldades enfrentadas pelos sujeitos colonizados para negociar o acesso à condição de cidadão, veja-se MENESES, Maria Paula, O 'indígena' africano e o colono 'europeu': a construção da diferença por processos legais. E-cadernos CES, Coimbra, n. 7, p. 68-93, 2010.

${ }^{35}$ Atual Maputo, capital de Moçambique.

${ }^{36}$ Polícia Internacional de Defesa do Estado, posteriormente transformada em Direção Geral de Segurança (DGS). A Pide-DGS foi a polícia política do regime colonial-fascista de Portugal.

${ }^{37}$ Como militante nacionalista, integrou o sistema de células clandestinas que possibilitaram a organização da Frente Sul. Cf. MBOA, Matias. Memórias da luta clandestina, op. cit.

${ }^{38}$ SILVA, Teresa Cruz e. A “IVa Região” da Frelimo no Sul de Moçambique: Lourenço Marques, 1964-65. Estudos Moçambicanos, Maputo, n. 8, p. 125-141, 1990.

${ }^{39}$ Como referido por vários entrevistados (ex-presos políticos e dois de seus advogados), muitos dos detidos políticos estavam sujeitos ao chamado processo administrativo, instruído pela Pide, e sem possibilidade de intervenção de advogados. Para a instrução destes "processos", as confissões eram obtidas usando várias formas de tortura: tortura do sono, da estátua, espancamentos, privaçáo de água e alimentos, uso da cela disciplinar etc. Estes processos nunca foram remetidos a tribunal e os presos eram "julgados" pela autoridade administrativa, sem a presença nem o conhecimento do arguido. A rede de
} 
Em 6 de julho de 1967 Domingos Arouca foi julgado pelo Tribunal Militar Territorial de Moçambique. Dentre as acusaçóes arroladas no processo destaca-se a de que ele teria desenvolvido

intensa atividade no sentido de preparar a eclosão de açôes terroristas da FRELIMO na região ao Sul do Save, pois convocou elementos, estabeleceu contatos e promoveu reunióes clandestinas, às quais presidia, nomeadamente as que tiveram lugar no gabinete da Direção do Centro Associativo dos Negros, de que era Presidente, no seu escritório de advogado, em sua própria casa e ainda em Benfica, local este sito na estrada de Marracuene. ${ }^{40}$

$\mathrm{Na}$ sequência do julgamento, Arouca foi considerado culpado pelos crimes de conjuração ou conspiração para a perpetraçáo de atos preparatórios de crimes contra a segurança exterior e interior do Estado e de instigação ou provocação à prática de crimes contra a segurança do Estado, tendo sido condenado a quatro anos de prisão maior, seis meses a três anos de medidas de segurança e quinze anos de suspensão dos direitos políticos.

Apesar de não existirem registros das provas utilizadas para confirmar as acusaçóes feitas contra Arouca, o fato é que ele passou oito anos recluso, a contar da data de sua detenção. Durante os primeiros anos foi mantido em Moçambique, na Cadeia da Machava. ${ }^{41}$ Ali - conforme documento assinado pelo inspetor adjunto da Pide local - teria sido sempre indisciplinado e considerado perigoso porque aproveitava qualquer oportunidade para difundir ideias subversivas, pondo em risco a disciplina e a segurança da cadeia que possuía mais de mil presos. Neste mesmo documento, datado de 6 de dezembro de 1967, "considera-se que a presença do preso Domingos Arouca na Cadeia da Machava se torna[va] dia a dia mais perigosa, pelo seu irriquietismo político e ainda pelo ascendente cultural e social sobre outros detidos com quem ocasionalmente contact[ass]e". ${ }^{42}$ Por esse motivo o funcionário responsável solicitava a

transferência do preso em questáo para estabelecimento prisional privativo desta Polícia em Lisboa, onde a sua presença não ofereceria qualquer perigo, não só quanto à Segurança da Cadeia como também porque, seguro se nos afigura, o ambiente no meio de brancos não será propício ao desenvolvimento de atividades político-separatistas, mas mesmo que o seja, tal atividade não tem a importância nem a perigosidade que aqui representa. ${ }^{43}$

Em 25 de junho de 1968 Arouca foi transferido para a Cadeia do Forte de Peniche em Portugal, de onde sairia apenas em 16 de junho de 1973, cumprida a pena na totalidade, acrescida de três anos de medidas de segurança. Nunca se beneficiou de qualquer desconto na pena pelo tempo em que esteve preso antes de ser julgado e condenado. Isto apesar de sua libertação ter sido permanentemente exigida em vários fóruns e de a Anistia Internacional tê-lo considerado “o preso político do ano" em 1972.

prisóes da Pide em Moçambique integrava a Fortaleza de Ibo, as prisóes de Nampula, Quelimane, Beira, Tete e Sommerschield (em Lourenço Marques, atual Maputo), o campo prisional da Machava, o campo de trabalho de Mabalane, entre outras. Estima-se que mais de 5 mil presos políticos passaram por esta rede de prisóes até 1974 .

${ }^{40}$ ANTT - PIDE/DGS - Domingos António Mascarenhas Arouca. Serv. Centrais Pc. 951/68. NT 6019. V. 1, fl. 37.

${ }^{41} \mathrm{O}$ complexo prisional da Machava, situado nas proximidades da então cidade de Lourenço Marques, destinava-se, inicialmente, a presos de delito comum. Com o advento dos protestos nacionalistas, a Pide criaria, em 1964, uma seção especial no complexo, destinada a opositores políticos e prisioneiros de guerra, designada Campo Prisional da Machava, ou ainda Campo de Recuperação da Machava. Circular no 19 da Comissáo Nacional de Socorro aos Presos Políticos, de 9 de maio de 1973. Disponível em: <www.25abril.org/index.php?content=2\&image=85\&serie=2>. Acesso em: 1a abr. 2013.

${ }^{42}$ ANTT - PIDE/DGS - Domingos António Mascarenhas Arouca. Serv. Centrais Pc. 951/68. NT 6019. V. 1, fl. 4-5. ${ }^{43}$ Ibid. 
Nenhum dos seus muitos pedidos de habeas corpus ou concessão de liberdade condicional foi deferido. Uma nota quanto a estes pedidos, produzida a 14 de fevereiro de 1970, justifica por que lhe era negada a liberação:

Embora haja cumprido já mais da metade da pena que lhe foi aplicada e exista, por esse motivo, o fundamento jurídico previsto no $\operatorname{art}^{\underline{0}} 120^{\circ}$ do Código Penal, afigura-se a esta Direção-Geral que [Domingos Arouca] não reúne os pressupostos legais indispensáveis que permitam elaborar a proposta para concessão da sua liberdade condicional, pois não lhe foram ainda assinalados quaisquer indícios de regeneração.

Crê-se mesmo que, uma vez em liberdade, ainda que condicionada, venha a ausentar-se do País e a tornarse um dos dirigentes da FRELIMO — Frente de Libertação de Moçambique — onde a sua açáo, como licenciado em Direito e subsequente grau de intelectualidade, poderá vir a ser altamente prejudicial à Nação. ${ }^{44}$

As autoridades coloniais portuguesas continuariam a considerar o dr. Arouca um elemento de alta periculosidade mesmo às vésperas do final do cumprimento do período máximo estipulado pelo mandato de segurança. O documento subscrito pelo diretor-geral da DGS, datado de 29 de maio de 1973 e dirigido ao ministro do Ultramar, é revelador da dimensão da preocupação em relação à projeção política que ele poderia vir a desempenhar:

O recluso DOMINGOS ANTÓNIO MASCARENHAS AROUCA virá a terminar o cumprimento da pena sofrida, no dia 18 do próximo mês de Junho.

Considerando, porém, que lhe não têm sido assinalados sintomas de recuperação social e continua, pelo contrário, a revelar a prevalecente disposição de reingressar nos quadros da FRELIMO que anseia a sua cooperação e prevendo-se, mesmo, que irá como principal dirigente ocupar o lugar de EDUARDO MONDLANE, tenho a honra de submeter o assunto à douta apreciaçáo de Vossa Excelência, a fim de que - concordando - se digne propor ao Venerando Conselho de Ministros que, nos termos do art $\mathbf{4}^{\mathrm{o}}$ do Decreto-Lei no 36 387, de 1 de Julho de 1947, lhe seja fixada residência pelo período de três anos numa das ilhas do arquipélago dos Açores, em face do fundado receio da repetição de graves crimes contra a segurança do Estado. ${ }^{45}$

Se olharmos superficialmente para a trajetória da FRELIMO, sobretudo para os últimos anos da luta armada, esta suposição de que Arouca, depois de libertado, poderia vir a ocupar o lugar de Mondlane soaria descabida, tendo em vista que:

a. desde 1970, sob a liderança política e militar incontestada de Samora Machel, forjou-se uma aparente coesão ideológica que reestruturou a FRELIMO em torno de um projeto político inspirado pela ideologia marxista-leninista;

b. Machel, enquanto líder militar, apostou na estratégia de avanço da luta armada. Em 1971 a FRELIMO dispunha já de uma apreciável organização político-administrativa em pleno funcionamento nas chamadas zonas libertadas, especialmente nas províncias nortenhas do Niassa, Cabo Delgado e em Tete. A partir desse ano, a progressão das ações armadas deste movimento desenvolveu-se sempre em crescendo, enquanto a situação militar portuguesa foi se deteriorando. A partir de 1973, a situação militar era já incontestavelmente favorável à FRELIMO, como reconhecem Afonso e Gomes. ${ }^{46}$

\footnotetext{
${ }^{44}$ Ibid., fl. 79.

${ }^{45}$ Ibid., fl. 146-147.

${ }^{46}$ AFONSO, Aniceto; GOMES, Carlos de Matos. Os anos da Guerra Colonial 1961-1975. Matosinhos: QuidNovi, 2010. p. 760.
} 
Entretanto, a hipótese de que Domingos Arouca poderia vir a ocupar um papel de liderança na cena política moçambicana ganha alguma plausibilidade quando se observa a presença de uma fratura política na FRELIMO, fruto da disputa entre aqueles que tentaram guiar o movimento exclusivamente no sentido da independência nacional e aqueles que adotaram uma perspectiva revolucionária inspirada pela ideologia marxista. Como sinalizavam Bragança e Depelchin, "as lutas entre [ess]as duas linhas, que vão praticamente de 1962 a 1970, não acabaram com a vitória da linha revolucionária [em 1970]. Foi muito mais um episódio duma luta prolongada". ${ }^{47}$

Tendo em conta a evidência de que a unidade da FRELIMO esteve permanentemente ameaçada ao longo da luta contra o colonialismo, o momento em que o dr. Arouca retornou a Moçambique reunia condiçôes de fato propícias à emergência de uma nova liderança política, nomeadamente de alguém que personificasse os interesses da linha nacional-independentista não revolucionária ou não marxista. Para tanto, pesava também o fato de que, em 1973, com a situação militar crescentemente desfavorável às Forças Armadas portuguesas, deu-se o início de um intenso processo de negociaçóes políticas cujo desfecho veio a ser o golpe de Estado do 25 de Abril e os acordos para a transição para a independência (sob a liderança da FRELIMO), assinados em 7 de setembro de 1974. Na historiografia oficial, este processo, que resultou na declaração da independência a 25 de junho de 1975, é celebrado por meio de várias datas comemorativas. Contudo, muitos aspectos das negociaçóes e atores envolvidos na construção do projeto da independência jazem no esquecimento.

Em 1973, as campanhas militares portuguesas aumentaram e o governo colonial avançou com a promessa de mudanças paulatinas, dentre as quais propunha a concessão de autonomia a Moçambique, mas sem abandonar o modelo integracionista da grande nação portuguesa pluricontinental. Uma das implicações desta mudança de estratégia política foi o apoio à consolidação de uma pequena burguesia negra que havia emergido em contexto urbano, especialmente nas cidades da Beira e de Lourenço Marques. Vários destes elementos afirmaram a sua posição nacionalista (favorável à autonomia/ independência), apesar de não terem aderido à versão marxista-leninista da Frelimo. Estes elementos ajudariam a compor o que Jorge Jardim ${ }^{48}$ chamaria de "Frente interna", da qual afirmava ser o líder. ${ }^{49}$ Foi este o ambiente que proporcionou o surgimento do Grupo Unido de Moçambique (Gumo), uma associação cívica sediada na Beira que defendia a autonomia de Moçambique. ${ }^{50}$ Ao mesmo tempo, no exterior continuavam a atuar, apesar do limitado impacto político, outros agrupamentos nacionalistas, como o Coremo ${ }^{51}$ e a Fumo. ${ }^{52} \mathrm{Ou}$ seja, embora a FRELIMO almejasse ser reconhecida como a única força nacionalista em Moçambique, no início da década de 1970 o contexto político revelava-se muito mais complexo.

Em princípios de 1973, o crescendo das ações militares realizadas pela FRELIMO e a degradação das condiçóes de segurança na regiáo, especialmente na província de Tete, levaram o governo da Zâmbia a temer uma possível generalização da guerra na África Austral. Nesta altura, Kenneth Kaunda,

\footnotetext{
${ }^{47}$ BRAGANÇA, Aquino de; DEPELCHIN, Jacques. Da idealização da Frelimo à compreensão da história de Moçambique, op. cit. p. 43.

${ }^{48}$ Ex-secretário de Estado de Salazar. Fixou-se em Moçambique na década de 1950, onde construiu um império econômico a partir do exercício do cargo de administrador de várias empresas do grupo Champalimaud. Gozava de influência junto aos governos do Malawi e da Zâmbia.

${ }^{49}$ COUTO, Fernando Amado. Moçambique 1974: o fim do império e o nascimento da nação. Lisboa: Caminho, 2011 . p. 191.

${ }^{50}$ Entrevista realizada a Máximo Dias, ex-líder do Gumo, em Maputo, em outubro de 2011.

${ }^{51}$ Comitê Revolucionário de Moçambique. Fundado em 1965, chegou a realizar algumas açóes militares no Zumbo, província de Tete. Em 1973, Uria Simango engrossaria suas fileiras numa tentativa de aglutinar todas as forças dispersas dissidentes da FRELIMO. Em 1974, já após o golpe de Estado de 25 de abril, assistir-se-ia à dissolução do Coremo (e de outros pequenos partidos que, entretanto, haviam surgido), dando origem ao Partido da Coligação Nacional (PCN), liderado por Simango.

${ }^{52}$ Frente Unida de Moçambique, que integrava dissidentes da FRELIMO e do Coremo.
} 
entáo presidente da Zâmbia, voltou a insistir na oferta de atuar como mediador para uma solução negociada do problema colonial entre Portugal e os movimentos de libertaçáo. Kaunda tentava, desde finais de 1965, mediar as negociaçôes na busca de uma solução para as guerras nacionalistas travadas na África Austral. ${ }^{53}$ Considerando o enquadramento geográfico da Zâmbia, um estado interior, sem acesso direto ao mar, cuja economia dependia das exportaçóes de crômio, cobre e das importaçóes de combustível e outros produtos básicos, e que se encontrava cercado por países hostis dominados por minorias brancas (Angola, Moçambique, Rodésia do Sul - atual Zimbábue e Namíbia), tendo como Estados fronteiriços amigos apenas o Malawi e a Tanzânia, compreende-se o interesse do presidente Kaunda numa soluçáo negociada para o problema colonial português na região austral do continente africano. Paralelamente a esta iniciativa, o governo da Zâmbia continuou a apoiar os movimentos de libertação. Permitiu a abertura de representaçóes oficiais, de campos de treino militar e a passagem de homens e materiais de guerra para as zonas de combate. Isto porque a política externa aplicada por Kaunda tinha como linhas mestras o não alinhamento e a busca da construção de amplos consensos, o que não foi uma postura fácil de manter no "quente" contexto da Guerra Fria na África Austral.

Figura 1

Configuraçáo da África Austral a partir dos anos 1970

Em Moçambique destacam-se as províncias de Tete e Niassa e o porto da Beira

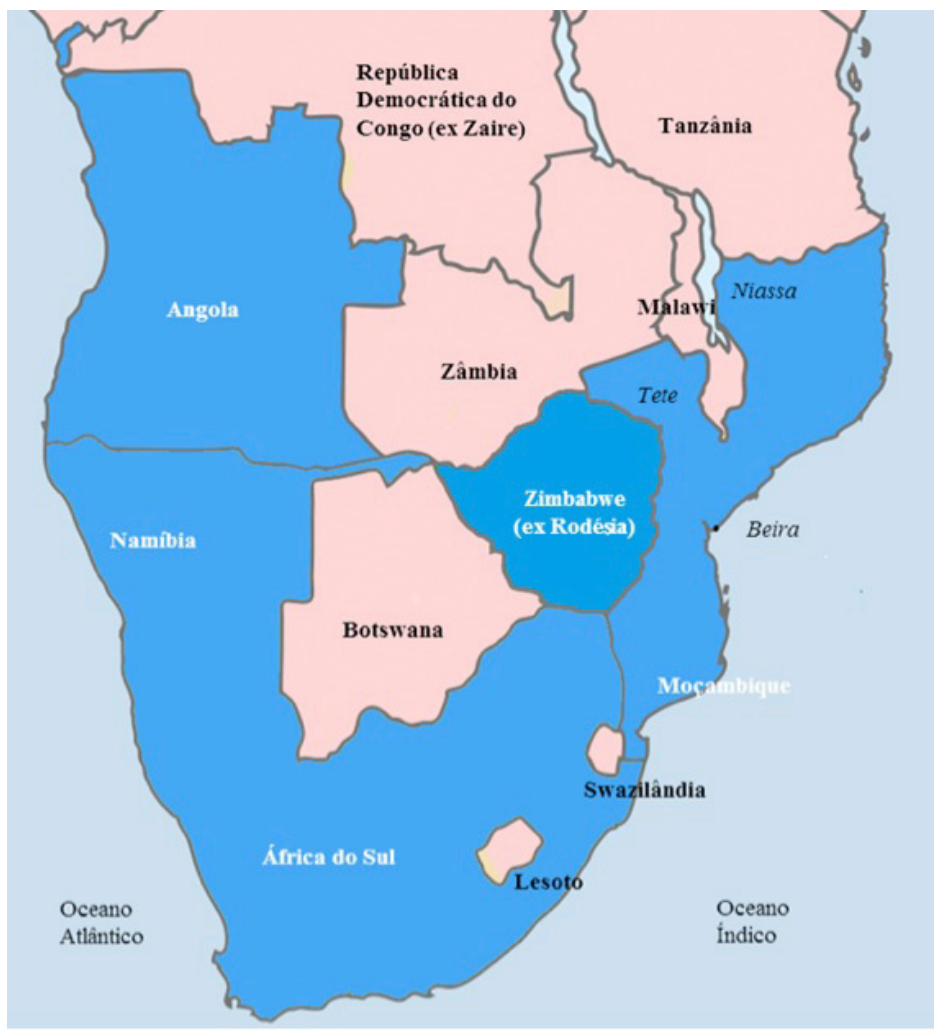

Fonte: Versão modificada a partir da figura publicada em MENESES, Maria Paula; MARTINS, Bruno Sena (Org.). As guerras de libertação e os sonhos coloniais: alianças secretas, mapas imaginados. Coimbra: Almedina, 2013. p. 9.

\footnotetext{
${ }^{53}$ Envolvendo múltiplos movimentos nacionalistas em Angola, Moçambique, Namíbia e Zimbábue. MENESES, Maria Paula; MARTINS, Bruno Sena (Org.). As guerras de libertaçâo e os sonhos coloniais: alianças secretas, mapas imaginados. Coimbra: Almedina, 2013.
} 
Como Shubin ${ }^{54}$ enfatiza, a regiáo austral do continente africano foi um dos espaços mais devastados pelos violentos conflitos que marcaram a última fase da Guerra Fria. A violência que atingiu a África Austral ao longo da segunda metade do século XX é inseparável do choque ideológico entre os blocos capitalista e socialista e seus respectivos projetos expansionistas. As guerras de libertação nacional, na perspectiva quer do bloco capitalista ocidental, quer da ex-União Soviética, foram frequentemente reduzidas à categoria de meros confrontos "locais" entre projetos imperiais. ${ }^{55}$ Por este motivo, voltar a atenção às agendas nacionalistas dos movimentos independentistas negros, em contraponto com o ambicioso projeto - liderado pela África do Sul — de manutenção da hegemonia branca e perpetuação da dominaçáo colonial no extremo Sul do continente, revela-se táo importante quanto reconhecer os impactos da Guerra Fria para compreender as dinâmicas político-militares que tiveram lugar na regiáo neste período histórico.

$\mathrm{Na}$ década de 1960, os governos de minoria branca instituídos na África Austral acreditavam que a regiáo, dada a sua crescente importância estratégica mundial, estaria sob a ameaça do comunismo global. Para defendê-la, estes governos formaram uma aliança cujo objetivo era combater os movimentos nacionalistas africanos, encarados como braços armados do comunismo. ${ }^{56} \mathrm{Em}$ contrapartida, os movimentos que lutavam pela independência reforçariam também suas estratégias de cooperação para além das fronteiras definidas pelas relaçôes coloniais. Forças nacionalistas sul-africanas, namibianas, angolanas, moçambicanas e zimbabuianas partilharam não só os centros de formação e treinamento político-militar de seus guerrilheiros, como também alguns espaços de combate pela liberdade, democracia e justiça social, formando assim uma multifacetada frente de luta contra um opositor comum: o projeto de hegemonia branco para a África Austral.

$\mathrm{Na}$ frente de Moçambique, a presença da FRELIMO na zona de Tete, a partir de 1968, e seu avanço, em 1972, para Manica e Sofala, centro do país, foram motivo de preocupação não apenas das autoridades portuguesas, mas também do governo rodesiano. Isto porque a progressão da guerrilha para o Sul ameaçava o acesso ao porto da Beira, fundamental para o abastecimento da Rodésia, e permitia ampliar a frente de luta de libertação: a FRELIMO passou a realizar açôes conjuntas com forças nacionalistas zimbabuianas..$^{57}$ Em resposta, o governo rodesiano reforçou a participaçáo ativa de suas tropas no palco de guerra em Moçambique. A participação da tropa rodesiana em açôes conjuntas com a tropa portuguesa foi denunciada várias vezes. ${ }^{58} \mathrm{Ou}$ seja, este quadro crítico demonstra que as preocupaçóes de Kenneth Kaunda quanto ao agravar da regionalização da guerra na África Austral estavam fortemente fundamentadas.

Foi neste contexto de elevada tensão que Jorge Jardim pretendeu assumir um papel político de destaque. No livro Moçambique terra queimada, Jardim relata detalhadamente como se deu sua aproximação a Kaunda e os encontros que resultaram na elaboração do documento conhecido como "Programa

\footnotetext{
${ }^{54}$ SHUBIN, Vladimir. The Hot Cold War. The USSR in Southern Africa. Scottsville: The University of Kwazulu-Natal Press, 2008.

${ }^{55}$ Veja-se: GLEIJESES, Piero. Conflicting missions. Havana, Washington, and Africa: 1959-1976. Chapel Hill: The University of North Carolina Press, 2002; WESTAD, Odd Arne. The global Cold War: third world interventions and the making of our times. Cambridge: Cambridge University Press. 2007; ONSLOW, Sue. Introduction. In: Southern Africa: white power, black liberation. Londres: Routledge. 2009. p. 1-8.

${ }^{56}$ Desde meados da década de 1960, África do Sul, Rodésia e Portugal começaram a esboçar o perfil de alianças econômicas bilaterais, bem como de pactos militares secretos de assistência mútua local, a adotar para "defender" o extremo Sul do continente africano. Em outubro de 1970, unidos por um interesse comum, esses países assinaram um acordo de cooperação para a manutenção da soberania de seus territórios. Esta aliança foi mantida em sigilo enquanto esteve em vigor, tendo recebido o discreto nome de Exercício Alcora. MENESES, Maria Paula; MARTINS, Bruno Sena (Org.). As guerras de libertação e os sonhos coloniais, op. cit.

${ }^{57}$ MOIANE, José P. Memórias de um guerrilheiro, op. cit. p. 145.

${ }^{58}$ Ibid., p. 132.
} 
de Lusaka”. Formalmente, o documento apresenta uma proposta do governo da Zâmbia, datada de 12 de setembro de 1973, contendo o "ponto de vista da Zâmbia na evolução dos territórios africanos portugueses" ${ }^{59}$ Enuncia também alguns princípios e mecanismos a serem seguidos num processo negocial com vista à independência de Moçambique e Angola, na sequência de propostas anteriores submetidas por Kaunda aos governos de Salazar e Marcello Caetano. Mas Jardim interpretou-o como um documento-chave que reunia as bases - previamente discutidas e aceites pelos governos da Zâmbia, do Malawi, da Tanzânia e pela própria Frelimo — ${ }^{60}$ de um acordo que lhe permitiria avançar com um projeto para a independência de Moçambique, e que assegurasse os interesses da minoria branca que ali residia. ${ }^{61}$

Joaquim Chissano, que coordenava as relaçôes exteriores do movimento, confirma que recebeu a proposta da Zâmbia e entregou-a pessoalmente a Samora Machel. Machel recomendou que a mesma passasse pela análise de um grupo muito restrito, do qual fizeram parte o próprio Chissano e Óscar Monteiro. Mas, nunca, apesar das pretensôes de Kaunda, ao longo deste processo, houve encontros entre a delegaçáo da FRELIMO e Jorge Jardim porque a Frente não admitia "negociar com uma pessoa que não tivesse mandato para tal", como era o caso de Jardim. ${ }^{62}$ Em finais de 1973, a resposta da FRELIMO foi entregue formalmente a Kaunda, com o conhecimento prévio de Julius Nyerere. ${ }^{63}$ Colocavam-se questôes de fundo, que necessitavam de uma completa reformulação, e exigia-se o reconhecimento de princípios do mandato negocial. Mas não se fechavam as portas à continuidade das negociaçôes. ${ }^{64}$

Por outro lado, Jardim também não encontrou receptividade por parte do governo português para pôr em marcha o seu plano de controlar os rumos da independência de Moçambique. $\mathrm{Na}$ avaliaçáo de Afonso e Gomes, este plano "não passou de um baláo de ensaio" que revelou a ausência de alternativas de um regime que "já não tinha sequer credibilidade para negociar o futuro das suas colônias com os movimentos de libertação". ${ }^{65}$ Como qualquer bom estrategista, Jardim possuía também um plano alternativo: executar um golpe de estado em Moçambique. ${ }^{66}$ De acordo com seus relatos, este segundo plano esteve muito perto de ser colocado em prática, o que só não ocorreu devido ao contexto regional que na altura lhe era pouco favorável: O Malawi, a Zâmbia e a Tanzânia apoiavam a independência incondicional de Moçambique na base de um projeto de raiz africana; os vários governos em Portugal após o golpe de Estado de 25 de abril mostraram-se avessos a negociar com Jardim, que chegou inclusive a ser preso, e a África do Sul do apartheid era então dirigida por um governo que apostava numa détente em face da agressividade anterior. $\mathrm{O}$ detalhe que nos interessa destacar ao mencionar os planos de Jorge Jardim é o fato de, numa reuniáo realizada a 23 de janeiro de 1974, com o propósito de discuti-los uma vez mais com o presidente zambiano, Jardim ter declarado expressamente que

considerava o meu amigo Dr. Domingos Arouca como elemento válido para participar, em qualquer das hipóteses, no elenco moçambicano considerando a sua formação universitária, a autoridade resultante da longa pena sofrida, a tolerância racial que evidenciava e o ambiente de respeito que a todos poderia merecer.

\footnotetext{
${ }^{59}$ PASSOS, Inácio de. Moçambique: a escalada do terror. Queluz: Literal, 1977. p. 160.

${ }^{60}$ MONTEIRO, Óscar. Testemunho de um jovem nas negociaçôes para a independência de Moçambique. Jornal Notícias: Suplemento dedicado aos 30 anos da independência, Maputo, 25 jun. 2005.

${ }^{61}$ JARDIM, Jorge. Moçambique terra queimada. Rio de Janeiro: Portugália, 1976. p. 7.

${ }^{62}$ CHISSANO, Joaquim. Apud COUTO, Fernando Amado. Moçambique 1974, op. cit. p. 192.

${ }^{63}$ Presidente da Tanzânia, país onde a Frelimo mantinha suas principais bases de apoio no exterior.

${ }^{64}$ COUTO, Fernando Amado. Moçambique 1974, op. cit. p. 193.

${ }^{65}$ AFONSO, Aniceto; GOMES, Carlos de Matos. Os anos da Guerra Colonial 1961-1975, op. cit. p. 742.

${ }^{66}$ JARDIM, Jorge. Moçambique terra queimada, op. cit. p. 177.
} 
[Kaunda] Pediu-me esclarecimentos sobre a personalidade do Dr. Arouca. Forneci-lhos e concluímos que se trataria de "homem-ponte" valioso que importava impulsionar. ${ }^{67}$

De acordo com a leitura de Couto, "nos planos independentistas de Jorge Jardim importava encontrar um moçambicano negro de renome para lhe dar credibilidade". ${ }^{8}$ Por esse motivo, em novembro de 1973, Jardim teria visitado o dr. Arouca para "sondar os planos políticos do advogado e tentar, através dele, uma aproximaçáo à FRELIMO, convencendo-o a participar nos seus planos. Nada de concreto foi estabelecido". ${ }^{69}$

$\mathrm{Na}$ altura em que recebeu a visita de Jorge Jardim, Domingos Arouca vivia com residência fixa na cidade de Inhambane, para onde havia sido conduzido diretamente, e sob escolta policial, ao deixar a cadeia em Portugal. Mantido sob constante vigilância da Pide/DGS, Arouca não tinha qualquer possibilidade de se reinserir imediata e plenamente no cenário político moçambicano, pelo menos até 25 de abril de 1974. Até esta data, as visitas de Jardim provavelmente foram os principais canais de atualização e atuação política ao seu alcance. Porém, segundo registra Couto, Arouca "sempre negou qualquer compromisso com Jorge Jardim". ${ }^{70}$

Depois do golpe de 25 de abril de 1974 Arouca passou a declarar publicamente sua fidelidade à Frelimo em entrevistas e discursos, reunidos no livro Discursos políticos. Acrescidos das peças fundamentais do Processo de Providência Extraordinária "Habeas Corpus", publicado ainda em 1974. Porém, essa calorosa tentativa de reaproximação encontraria uma fria recepção por parte das principais lideranças do movimento. Se, por um lado, a FRELIMO, que ele conhecera em 1963, havia evoluído em termos ideológicos, por outro, um intelectual negro nacionalista, democrata, ex-preso político e figura pública de prestígio (tanto interno, dada a sua atuação como advogado na comarca de Lourenço Marques e também pelo fato de ter sido o último presidente do Centro Associativo dos Negros de Moçambique, quanto externo, devido às várias campanhas organizadas pela Anistia Internacional a favor da sua libertação) parecia ter o perfil ideal para ocupar o papel de liderança que faltava à linha mais moderada dos nacionalistas presentes no país. Portanto, dar muito crédito e visibilidade ao dr. Arouca punha em risco a manutenção da aparente unidade da FRELIMO, que se apresentava como a única força política credível. Essa unidade, ainda que aparente, foi um dos pilares garantidores da força da FRELIMO no xadrez das negociaçóes para a independência.

Dado que a posição do governo que assumiu o poder logo a seguir ao golpe de Estado em Portugal revelou ser bastante ambígua em relação à solução para o problema colonial, a resposta da FRELIMO foi intensificar o combate político-militar contra o colonialismo e seus agentes. Perante a ameaça de um desastre militar, o governo português aceitaria reabrir as negociaçôes, do que resultaram os já mencionados acordos de 7 de setembro de 1974, que agendaram a independência definindo em que moldes e para quem seria transferido o poder.

Vencedora tanto nos campos de batalha militar como política, a FRELIMO assumiu-se como "a organização dirigente do Povo moçambicano", ${ }^{71}$ passando a denunciar os vários agrupamentos políticos que emergiram na sequência da abertura promovida pelo 25 de abril como "grupos fantoches colaboracionistas ao serviço do colonialismo". ${ }^{72}$ Em nome do povo, e defendendo a necessidade da manutençáo de uma frente única e unida para a transformação de Moçambique, a FRELIMO adotou uma postura de total intransigência diante de qualquer tentativa de oposição, que seria vista como "ação inimiga".

\footnotetext{
${ }^{67}$ Ibid., p. 178-179.

${ }^{68}$ COUTO, Fernando Amado. Moçambique 1974, op. cit. p. 220.

${ }^{69}$ Ibid.

${ }^{70}$ Ibid., p. 221.

${ }^{71}$ MACHEL, Samora Moisés. A luta continua: antologia de discursos do presidente da Frelimo. Porto: Afrontamento, 1974. p. 16.

${ }^{72}$ Ibid., p. 19.
} 
$\mathrm{Na}$ sequência das convulsões políticas que terminaram nos violentos episódios de 7 de setembro de 1974, ${ }^{73}$ vários personagens políticos foram considerados "traidores da causa do povo" que a FRELIMO simbolizava. Para aqueles que se identificaram como moçambicanos, a reação da FRELIMO foi específica: classificados como "inimigos", foram sujeitos a um julgamento "revolucionário e popular", presidido por Machel, em Nachingwea (Tanzânia), entre março e maio de 1975. Na sequência destes julgamentos, foram considerados traidores e condenados ao internamento em centros de reeducação. ${ }^{74}$ Essa medida tinha por objetivo libertar os transgressores, pelo envolvimento na prática do trabalho com o povo, das influências que os haviam levado a cometer o crime ou a desencadear o conflito. Os transgressores tinham de ser reeducados pelo povo para serem reintegrados na sociedade, um processo que a FRELIMO assumia como conducente à (re)criação do cidadão. Associadas ao trabalho, a crítica e autocrítica políticas e o estudo político eram também atividades vistas como fundamentais no processo de transformação dos "transgressores" em "homens novos". 75

As desconfianças em relação aos que não estiveram com a FRELIMO desde a luta e mesmo em relação àqueles militantes que, por motivos vários (inclusive por terem sido presos), não participaram ativamente na luta armada, cresceram. E assim, os oito anos em que Arouca esteve detido e isolado dos seus companheiros de militância refletiram-se num ostracismo político que acabaria prolongado por vários anos, não só imediatamente posteriores à sua libertação como também subsequentes à independência de Moçambique. Apesar de ser um quadro qualificado e participativo da frente de oposição ao colonial-fascismo em Moçambique, ao sair da prisão, Domingos Arouca náo mereceu a confiança política dos líderes da FRELIMO. Pelo contrário, como muitos outros presos políticos durante o período colonial, Arouca fez parte de um grande e extremamente heterogêneo grupo de pessoas identificadas pelo partido Frelimo como "comprometidos" com o colonialismo. Considerados "inimigos em potencial" da nação recém-instituída, muitos dos moçambicanos identificados como "comprometidos" foram enviados para campos de reeducaçáo e/ou centros de treinamento político-militar depois de julgados e condenados pela "justiça popular". Segundo os depoimentos de alguns ex-presos políticos que vivenciaram essa experiência, tratou-se de uma espécie de "exame, não só em termos de capacidade, mas também para ver até que ponto se podia ter confiança naqueles elementos, naquelas pessoas"; $;{ }^{76}$

(...) no fundo, foi uma maneira de redimir os presos, para deixarem de pensar que a direçáo máxima do Partido ainda estava desconfiada. Foi a maneira que ele [Samora Machel] encontrou de aproximar as pessoas. Antes dos treinos até nos disse:

"- Neste momento estou a falar com pessoas que não conheço. Consideremo-nos 'inimigos".

Mas, no dia de encerramento do curso, em Matalane, afirmou:

“- Agora vocês são camaradas, porque já conhecem a filosofia da FRELIMO, já 'ferveram' na mesma panela que nós, já somos iguais”.

\footnotetext{
${ }^{73}$ Sentindo-se excluído e ultrapassado pelo processo político, um grupo de colonos brancos promoveu um levantamento violento em Lourenço Marques como uma forma de protesto contra a transferência unilateral do poder para a FRELIMO. Politicamente, o episódio refletiu o agregar dos interesses de vários grupos que defendiam propostas neocoloniais para Moçambique, como uma solução à rodesiana, ou simplesmente se opunham à FRELIMO. Durante quatro dias a populaçáo branca expressou sua revolta ocupando a Rádio Clube de Moçambique e o aeroporto; libertando uma centena de agentes da Pide/DGS das cadeias onde estavam detidos; e percorrendo os subúrbios, ameaçando e matando civis negros identificados como membros da FRELIMO. As perturbaçôes foram contidas pela intervenção da tropa portuguesa com apoio das tropas da FRELIMO, que entretanto chegara ao sul de Moçambique na sequência dos acordos de paz de 7 de setembro.

${ }^{74}$ Sobre os campos de reeducação mantidos pela Frelimo veja-se: SÁ, José Pinto de. Os campos da vergonha. Público Magazine, 25 jun. 1995. Ilustrada, p. 17-34.

${ }_{75}$ MACHEL, Samora. O partido e as classes trabalhadoras moçambicanas na edificaçâa da democracia popular, op. cit.

${ }^{76}$ MALANGATANA. Apud MATEUS, Dalila Cabrita (Org.). Memórias do colonialismo e da guerra. Porto: Ediçóes Asa, 2006. p. 643.
} 
Samora precisava de pessoas em certos setores e não tinha quadros de confiança. Ora, para conhecer as pessoas foi necessário "agarrar" nos que tinham estado presos para ver se, de fato, tinham mudado de ideias, se não se tinham passado para o lado do inimigo. E para completar isso foi necessário passar pelos treinos de preparação militar, para as pessoas voltarem àquilo que eram, mas com uma preparação um bocado maior. ${ }^{77}$

Malangatana reconhece que passada a fase das perseguições e reeducaçôes, ele e muitos dos ex-presos políticos rotulados de 'comprometidos' ocuparam cargos de responsabilidade no partido ou no governo. ${ }^{78}$ Outros parecem nunca ter se reintegrado. Estes, quando depóem sobre as reunióes com os ex-presos políticos dirigidas por Samora Machel e sobre a experiência da reeducaçáo, apresentam uma perspectiva crítica sobre as razões deste processo:

Essa reunião foi uma tentativa de nos dividir e de sublinhar que os antigos presos políticos não tinham feito a guerra na luta de libertação. Ora não haveria luta sem trabalho clandestino (...)

Nós que iniciamos a luta na clandestinidade, não estivemos à espera que os guerrilheiros nos viessem educar. Como é que Samora queria ver até que ponto ia a nossa militância? Se fomos nós que criamos as condiçôes para receber aqui a FRELIMO, as condições e as bases materiais! ${ }^{79}$

Talvez mais do que nenhum outro ex-preso político, Domingos Arouca reuniu, ao longo de sua trajetória, inúmeras das características que seriam indicativas de colaboracionismo com a antiga ordem colonial, de acordo com a perspectiva do governo moçambicano no imediato pós-independência. Arouca estudou na metrópole durante os anos de maior efervescência política entre os estudantes provenientes de todas as então colônias portuguesas em África, reunidos na Casa dos Estudantes do Império, mas não há qualquer indício de que tenha participado deste movimento estudantil que alimentaria a formação dos movimentos nacionalistas que logo se lançariam na luta armada contra o colonialismo português. Pelo contrário, nessa altura chegou literalmente a ser "colaborador permanente do Centro de Estudos Políticos e Sociais do Ministério do Ultramar". ${ }^{80}$ Segundo o depoimento de outros ex-presos políticos, enquanto esteve na cadeia da Machava recebeu tratamento diferenciado:

(...) deram tratamento de favor ao Dr. Arouca, também este tinha livros na cadeia. Havia um processo seletivo, que não ia só pela cor da pele, ia também pelo estatuto civil do preso. O Dr. Arouca não era branco, mas era casado com uma senhora branca e era doutor, portanto o tratamento era outro. ${ }^{81}$

(...) a comida para o Arouca vinha da pensão. ${ }^{82}$

[Arouca] não era maltratado. Ou, antes, era maltratado psicologicamente, quando era chamado à delegaçáo, à Vila Algarve. Mas na cadeia os guardas tinham medo dele.

(...)

O Dr. Arouca se estivesse doente não era tratado lá na cadeia, ia para a cidade. Era tratado com certa deferência. ${ }^{83}$

\footnotetext{
${ }^{77}$ CHIVITE, Simione Sambane. Apud MATEUS, Dalila Cabrita (Org.). Memórias do colonialismo e da guerra, op. cit. p. 625.

${ }^{78}$ MALANGATANA. Apud ibid., p. 643.

${ }^{79}$ MBAZIMA, Muheti Juchua. Apud ibid., p. 539-541.

${ }^{80}$ AROUCA, Domingos. Análise social do regime do indigenato. s.l.: Tip. Centro Social Ldª 1961.

${ }^{81}$ MAGAIA, Albino. Apud MATEUS, Dalila Cabrita (Org.). Memórias do colonialismo e da guerra, op. cit. p. 49.

${ }^{82}$ BUCUANE, Aurélio. Apud ibid., p. 171.

${ }^{83}$ CHIVITE, Simione Sambane. Apud ibid., p. 629.
} 
Mas alguns dos companheiros dos tempos de detenção na Machava reconhecem que o tratamento diferenciado dado ao dr. Arouca não o favoreceu, pelo contrário; ele foi mantido sempre em regime de isolamento. Para Matias Mboa ${ }^{84}$ que reconhece na cadeia um espaço onde os militantes presos puderam adquirir "uma consciência política válida", ${ }^{85} \mathrm{o}$ isolamento de Arouca teria sido um fator determinante para o seu afastamento em relação à FRELIMO.

(...) é muito difícil encontrar um antigo preso político, que tivesse abandonado a FRELIMO. Isso graças ao trabalho feito dentro da cadeia. É difícil encontrar. Mas você pode perguntar:

"-E, então, o Arouca?"

Pois, o Arouca [ffffff] ]. Abandonou a FRELIMO, porque não beneficiou da consciencialização política que nós tivemos. Vivia sozinho, não falava com ninguém, não tinha recreio conosco. Vivendo só, a situação foi outra. Mas todos os outros que foram presos políticos são da FRELIMO dos pés à cabeça. ${ }^{86}$

Isolado, Arouca não teve a oportunidade de "ferver" nem na panela dos que estiveram presos, nem na panela dos que tinham estado na luta armada. Ou, por outras palavras, tendo sido interrompida prematuramente, sua formação como militante nunca chegaria a completar-se, pois não teve acesso a nenhuma das "escolas" que forjariam os quadros da FRELIMO na guerra de libertação nacional.

Fato é que "o Dr. Arouca nunca iria receber ordens do Partido [Frelimo]". ${ }^{87}$ Embora houvesse chegado a ser convidado para integrar o governo de transição, liderado pela FRELIMO, viria a recusar. ${ }^{88}$ Aferrado às suas concepçóes políticas democráticas e anticomunistas, Arouca fundou a Frente Unida Democrática de Moçambique, que adotou a sigla Fumo. No documento datado de 23 de setembro de 1976, através do qual tornou pública a existência da Fumo, Domingos Arouca apresentou duras críticas à FRELIMO denunciando o "cortejo de fuzilamentos, prisôes em massa e abolição de todos os direitos humanos; tudo [feito] em nome da revoluçáo socialista". ${ }^{89}$ Depois disso, para escapar ao destino dos "inimigos", autoexilou-se em Portugal.

Em 1992, após a adoção do pluralismo político em Moçambique, retornou ao país como líder da Fumo, transformada num partido de oposição. Seu partido nunca chegou a ocupar um lugar de destaque no cenário político moçambicano, recebendo sempre um número ínfimo de votos. Mas sua participação, ainda que pequena, cumpria a importante função de indicar a existência de um outro caminho para Moçambique e para moçambicanos e moçambicanas, assinalando que a política, assim como a história, é um espaço de disputa onde todos os cidadãos, independentemente da sua cor, religião, classe social, gênero ou ideologia, deveriam estar representados.

\section{Considerações finais}

Em Moçambique, as relaçóes coloniais, o imperialismo e a descolonização permanecem temas em aberto e são cada vez mais revisitados para promover o questionamento do macro quadro historiográfico construído em torno da Guerra Fria. Ainda hoje as narrativas que relembram as razóes que levaram

\footnotetext{
${ }^{84}$ Matias Mboa é um antigo militante da FRELIMO. Um dos dirigentes da IVa Região, foi preso ainda em 1964 e libertado muitos anos depois, em 1973. Veja-se MBOA, Matias, Memórias da luta clandestina, op. cit.

${ }^{85}$ MBOA, Matias. Apud MATEUS, Dalila Cabrita (Org.). Memórias do colonialismo e da guerra, op. cit. p. 507.

${ }^{86}$ Ibid.

${ }^{87}$ GUAMBO, Caetano Filipe. Apud ibid., p. 190.

${ }^{88}$ Conversa com Ruy Baltazar, realizada em Maputo, em outubro de 2011.

${ }^{89}$ FUMO. Programa e Estatutos. Lourenço Marques, 1976. p. 3. Mimeografado.
} 
ao sucesso da luta armada do povo moçambicano contra o colonialismo continuam a insistir na demarcação entre os "bons" moçambicanos, entendidos como aqueles que se envolveram na luta armada, e os "maus", os "inimigos" que traíram a causa, seja por terem se alinhado antes da independência com o regime colonial, seja por terem criticado e desafiado a liderança política que a Frelimo procurou (e continua a procurar) manter na definição do projeto nacional. A traiçáo também tem sido um tema latente no panorama da história política moçambicana. Sendo frequentemente o produto de obrigaçóes políticas e sociais contraditórias, no caso moçambicano, a ideia de traição carrega uma ambiguidade que desafia a lógica moral subjacente aos binômios revolucionário/reacionário, amigo/inimigo, vítima/ responsável.

Em abril de 1990, Joaquim Chissano, então presidente de Moçambique, solicitou ao dr. Domingos Arouca que esboçasse uma proposta para uma nova constituição moçambicana. Arouca assim o fez. ${ }^{90}$ O país precisava adequar-se à paz e ao exercício da democracia. Nesse processo foram "esquecidas" as acusaçốes de traição e o antigo rótulo de "inimigo" deixou de fazer sentido.

Domingos Arouca faleceu por causas naturais em 2009, em Maputo. Dois anos antes, amigos e familiares organizaram-lhe uma homenagem por ocasiáo do seu octogésimo aniversário da qual participaram o dr. Ruy Baltazar, entáo presidente do Conselho Constitucional, que fez uso da palavra "para repor a verdade histórica sobre o Dr. Domingos Arouca", ${ }^{91}$ e o ministro Cadmiel Muthemba, ${ }^{92}$ enviado pelo próprio chefe de Estado para ler uma mensagem elogiosa à figura do homenageado.

Contudo, não foi esse reconhecimento tardio o que garantiu o lugar de Domingos Arouca no hall das memoráveis personagens da história moçambicana. O que seu percurso demonstra é uma incessante batalha não para ver-se inscrito na história de Moçambique, mas para ajudar a escrever outra história para este país. Com o seu "irriquietismo político" Arouca conseguiu ao menos manter sempre presente a perspectiva de que nunca houve um único destino possível para Moçambique e para os moçambicanos e moçambicanas, ainda que aqueles que ditam a história oficial muitas vezes tenham desejado fazer crer o contrário.

\footnotetext{
${ }^{90}$ Radio Maputo. Mozambique: exiled lawyer sends Chissano draft constitution. Londres, 20 jul. 1990. Disponível em: <www.mozambiquehistory.net>. Acesso em: 31 jan. 2012.

${ }^{91}$ LOFORTE, Luís. Homenagem ao dr. Domingos Arouca - Organizamos, por isso desmentimos, Moçambique para todos, 1 nov. 2010. Disponível em: <http://macua.blogs.com/moambique_para_todos/2010/11/homenagem-ao-dr-domingos-arouca-organizamos-por-isso-desmentimos.html>. Acesso em: 1ํo fev. 2012.

92 Ex-preso político, esteve na cadeia da Machava no mesmo período em que lá esteve Domingos Arouca.
} 